\title{
Pidana Kerja Sosial, Tokyo Rules, serta Tantangannya di Masa Mendatang
}

\author{
Maria Ulfah ${ }^{1}$
}

${ }^{1}$ Fakultas Hukum Universitas Katolik Parahyangan, e-mail: ulfah0212maria@gmail.com

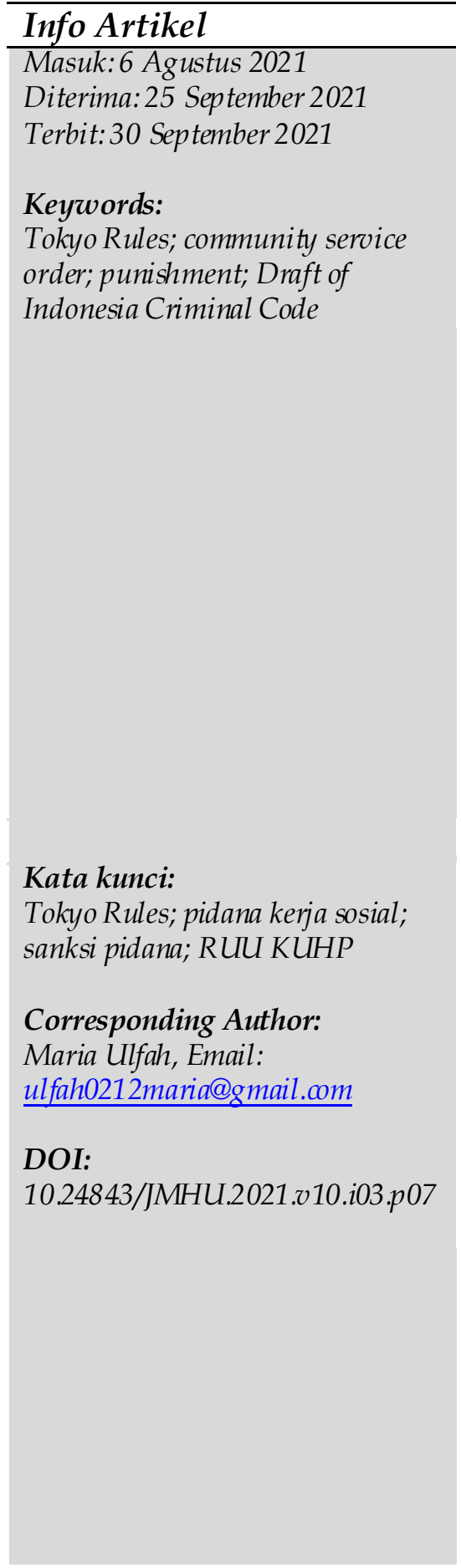

\begin{abstract}
Community service order is one of the alternative sanctions from short-term imprisonment and light fines as regulated in Artide 65, Artide 82, and Artide 85 of the Draft of Indonesia Criminal Code on the September 2019 (RUU KUHP). Community service order is expected to be the one solution for the overcrowded state of Correctional Institutions in Indonesia due to the large number of articles with imprisonment. Community service order as a new criminal sanction in the future requires further arrangements that can support its implementation in the future and it is possible that several challenges arise in its implementation. The contents of further regulations related to community service order in this research are explored through general guidelines in the international law, namely the Tokyo Rules (UN General Assembly Resolution Number 45/110). This research uses qualitative research with normative juridical research methods in the form of analytical descriptive. The result of this study is twenty-two provisions in the Tokyo Rules can be used as a guide in determining the contents of further regulations related community service order. In addition, the factors can become challenges must be carefully considered by legal policy makers so that they are minimized in the implementation of community service order in the future.
\end{abstract}

\begin{tabular}{l}
\hline Abstrak \\
\hline Pidana kerja sosial adalah salah satu sanksialternatif dari pidana \\
penjara jangka waktu pendek maupun sanksi pidana denda \\
ringan yang diatur dalam Pasal 65, Pasal 82, dan Pasal 85 \\
Rancangan Undang-Undang tentang Kitab Undang-Undang \\
Hukum Pidana September 2019 (RUU KUHP). Pidana kerja \\
sosial diharapkan menjadi salah satu solusi dari keadaan \\
overcrowded Lembaga Pemasyarakatan di Indonesia akibat \\
banyaknya pasal dengan sanksi pidana penjara. Pidana kerja \\
sosial sebagai sanksi pidana baru di masa mendatang \\
membutuhkan pengaturan lebih lanjut yang dapat mendukung \\
implementasinya di masa mendatang dandimungkinkan muncul \\
beberapa tantangan dalam implementasinya. Isi dalam \\
pengaturan lebih lanjut terkait pidana kerja sosial dalam \\
penelitian ini dapat digali melalui pedoman umum dalam dunia \\
internasional yakni Tokyo Rules (Resolusi Majelis Umum PBB \\
Nomor 45/10). Penelitian ini menggunakan penelitian kualitatif \\
dengan metode penelitian yuridis normatif berbentuk deksriptif \\
analitis. Hasil dari penelitian ini adalah adanya dua puluh dua \\
ketentuan dalam Tokyo Rules yang dapat menjadi panduan \\
dalam menentukan isi pengaturan lebih lanjut terkait pidana
\end{tabular}


kerja sosial. Selain itu, faktor-faktor yang dapat menjadi tantangan harus dipikirkan secara matang oleh pembuat kebijakan hukum agar terminimalisir dalam pelaksanaan pidana kerja sosial di masa mendatang.

\section{Pendahuluan}

Penjara sebagai sebuah sanksi pidana dikenal di Indonesia sejak zaman penjajahan Belanda. Penjajah Belanda membentuk Wetboek van Strafrecht voor Nederlandch Indie atau Wetboek van Strafrecht (sekarang disebut Kitab Undang-Undang Hukum Pidana/ KUHP) pada Oktober 1915 dan memberlakukannya pada Januari 1918. ${ }^{2}$ Pasal 10 KUHP menjadi landasan hukum dalam pengaturan sanksi pidana penjara sebagai pidana pokok dalam suatu tindak pidana.

Bermula dari pengaturan pidana penjara dalam beragam pasal di Buku II KUHP, lalu berkembang pada banyak pasal yang tersebar dalam Undang-Undang di luar KUHP. Berdasarkan data penelitian pada periode tahun 1998 hingga 2014 diketahui bahwa 154 aturan berbentuk Undang-Undang (dari total 563) memiliki aturan pidana. Sebagian besar dari 154 aturan tersebut terdapat 654 tindak pidana (atau sejumlah 91.34\%) menggunakan penjara sebagai sanksi pidana. $^{2}$

Jumlah pengaturan tindak pidana dengan sanksi pidana penjara yang begitu tinggi dari data di atas, maka permasalahan jumlah hunian di lembaga pemasyarakatan (lapas) menjadi isu yang terus bergulir setiap waktu di Indonesia. Dikatakan oleh Reynhard Silitonga selaku Direktur Jenderal Pemasyarakatan pada situasi terkini bahwa kapasitas hunian di Lembaga Pemasyarakatan (Lapas) dan Rumah Tahanan (Rutan) Indonesia adalah 132.107 penghuni, sehingga biaya operasional sangat besar yang harus dikeluarkan negara. ${ }^{3}$ Kondisi hunian Lapas dan Rutan dalam lima tahun terakhir juga meningkat sekitar 130.000-an sehingga diperkirakan dalam lima tahun ke depan akan terjadi peningkatan sama. ${ }^{4}$ Persoalan overcrowding perlu dipikul bersama oleh seluruh elemen pemerintah, Aparat Penegak Hukum (APH), hingga masyarakat bukan hanya menjadi tanggung jawab Direktorat Jenderal Pemasyarakatan (Ditjenpas). ${ }^{5}$ Ditegaskan pula oleh Walikota Pasuruan, Saifullah Yusuf bahwa masalah overcrowded memicu banyak kasus (seperti kerusuhan), sehingga diusulkan pembangunan Lapas yang lebih luas dan terintegrasi di Kota Pasuruan. ${ }^{6}$

1 Topo Santoso, Hukum Pidana Suatu Pengantar. (Depok: PT RajaGrafindo Persada, 2020), 238239.

2 Anugrah Rizki Akbari, Potret Kriminalisasi Pasca Reformasi dan Urgensi Reklasifikasi Tindak Pidana di Indonesia. (Jakarta: Institute for Criminal Justice Reform, 2015), 10-15.

${ }^{3}$ Direktorat Jenderal Pemasyarakatan Kementerian Hukum dan HAM Republik Indonesia, Atasi Overcrowded, Ditjenpas Dukung Rehabilitasi Pengguna Narkotika, http:// www.ditjenpas.go.id/atasi-overcrowded-ditjenpas-dukung-rehabilitasi-penggunanarkotika (diakses 27 Juli 2021).

4 Ibid.

${ }^{5}$ Ibid.

${ }^{6}$ Direktorat Jenderal Pemasyarakatan Kementerian Hukum dan HAM Republik Indonesia, Ditjenpas Akan Bangun Lapas Terintegrasi Pesantren dan Panti Rehabilitasi di Jawa Timur, 
Berikut ini adalah data relevan mengenai grafik pertumbuhan jumlah narapidana di Indonesia (2015-2020) ${ }^{7}$ dan tabel jumlah narapidana di Indonesia (2015-2019) ${ }^{8}$ yang menunjukkan terjadinya kelebihan jumlah hunian lapas sebagaimana dimaksudkan dalam kedua pendapat di atas:

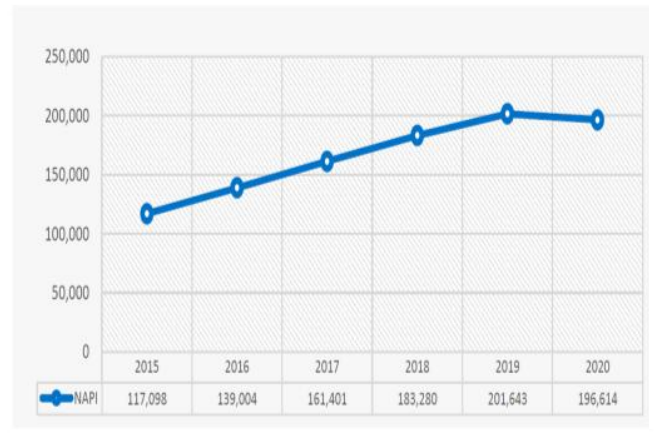

Table 1. Prison capacity in Indonesia

\begin{tabular}{|l|l|l|l|c|}
\hline No & Year & Inmate & Capacity & Overcapacity \\
\hline 1 & 2015 & 176.754 & 119.797 & $\mathbf{1 4 7 \%}$ \\
\hline 2 & 2016 & 204.551 & 119.797 & $\mathbf{1 7 0 \%}$ \\
\hline 3 & 2017 & 232.081 & 123.481 & $\mathbf{1 8 8 \%}$ \\
\hline 4. & 2018 & 256.273 & 126.273 & $\mathbf{2 0 2 \%}$ \\
\hline 5 & 2019 & 269,846 & 130.512 & $\mathbf{2 0 6 \%}$ \\
\hline \multicolumn{5}{|c|}{ (Sources: Correctional database system, January 10 th $^{\text {th }}$ 2020) }
\end{tabular}

Pembahasan kelebihan jumlah hunian di lapas pada masa pandemi covid yang terjadi sejak kisaran Januari 2020 di Indonesia juga semakin menjadi perhatian. Sejak awal pandemi covid, Kementerian Hukum dan Hak Asasi Manusia (Kemenkuham) menerbitkan Peraturan Menteri Hukum dan Hak Asasi Manusia (Permenkumham) Nomor 10 Tahun 2020 terkait pemberian asimilasi dan hak integrasi bagi Warga Binaan Pemasyarakatan dan penerapannya telah membuat 69.006 narapidana dan Anak penerima hak Asimilasi di rumah serta 55.929 narapidana dan 1.415 Anak penerima hak integrasi. 9 Permenkumham tersebut dicabut dan diperbaharui dengan Permenkumham Nomor 32 Tahun 2020 yang sejak penerapannya telah membuat 21.096 narapidana dan Anak menjalankan Asimilasi di rumah serta 16.387 narapidana dan 309 Anak menerima hak Integrasi.10

Perubahan terkini dilakukan atas Permenkumham tersebut menjadi Permenkumham Nomor 24 Tahun 2021. Reynhard Silitonga menyatakan bahwa perubahan aturan ini harus segera dilakukan sebagai penanganan lanjutan dalam upaya mencegah semaksimal mungkin potensi penyebaran COVID-19 di Lapas, Rutan, dan LPKA.11 Evaluasi terus dilakukan sejak awal pandemi berlangsung di tahun 2020, dengan harapan akan semakin banyak yang melaksanakan hak Asimilasi dan Integrasinya di rumah (tentunya dengan pengawasan dari Pembimbing Kemasyarakatan di Balai

http://www.ditjenpas.go.id/ditjenpas-akan-bangun-lapas-terintegrasi-pesantren-dan-pantirehabilitasi-di-jawa-timur (diakses 3 Mei 2021).

7 Tim Penyusun Laporan Kinerja Instansi Pemerintah Ditjenpas 2020, Laporan Kinerja Direktorat Jenderal Pemasyarakatan Tahun 2020, (2021), Jakarta: Direktorat Jenderal Pemasyarakatan, h. 74 .

${ }^{8}$ Ejo Imandeka \& Zulfikri, "Preventing Coronavirus in Overcrowded Prisons in Indonesia", Proceedings of the 1st International Conference on Law and Human Rights 2020 (ICLHR 2020) dalam Advances in Social Science, Education and Humanities Research, vol. 549 (2020): 155. https://dx.doi.org/10.2991/assehr.k.210506.022

9 Direktorat Jenderal Pemasyarakatan Kementerian Hukum dan HAM Republik Indonesia, Darurat Cegah Penyebaran COVID-19, Asimilasi di Rumah bagi Narapidana dan Anak Diperpanjang, http://www.ditjenpas.go.id/darurat-cegah-penyebaran-covid-19-asimilasi-di-rumah-baginarapidana-dan-anak-diperpanjang (diakses 1 Juli 2021).

10 Ibid.

11 Ibid. 
Pemasyarakatan) serta masyarakat mau berperan dengan mengawasi dan mendukung pelaksanaan Asimilasi di rumah. ${ }^{12}$

Melihat pada beragam pendapat serta data di atas, tampak jelas bahwa jumlah hunian lapas yang berlebih dari kapasitas seharusnya merupakan permasalahan utama yang membutuhkan solusi dari beragam aspek. ${ }^{13}$ Solusi tersebut tidak terbatas hanya pada penambahan atau perluasan bangunan lapas, maupun pada perubahan aturan mengenai asimilasi atau hak intergrasi. Diperlukan solusi-solusi lain yang mendukung agar lapas di Indonesia menjadi lebih baik daripada situasi saat ini.

Salah satu solusi yang dapat diusulkan untuk membantu permasalahan kelebihan jumlah hunian lapas di atas ialah adanya sanksi pidana baru yang tidak berorientasi pada penjara dan dirumuskan secara berkelanjutan dalam pasal-pasal yang memuat sanksi pidana. Wacana sanksi pidana baru telah muncul sejak tahun 1963 melalui Rancangan Undang-Undang tentang Kitab Undang-Undang Hukum Pidana (RUU KUHP). ${ }^{14}$ Rancangan terakhir yang ada saat ini ialah RUU KUHP September 2019.15

Sanksi pidana baru dalam RUU KUHP sebagai salah satu solusi dari permasalahan jumlah hunian yang berlebih di lapas ditegaskan oleh Wakil Menteri Hukum dan Hak Asasi Manusia Edward Omar Sharif Hiariej. ${ }^{16}$ Akan tetapi, hingga tahun 2021 ini belum berhasil disahkan dan masih menuai pro dan kontra. ${ }^{17}$ Semoga RUU KUHP ini segera disahkan agar kita sebagai bangsa merdeka memiliki KUHP khas Indonesia, bukan khas dari penjajah yang belum berbahasa Indonesia.

Sanksi pidana baru dalam RUU KUHP September 2019 diatur dalam Pasal 65-66. Beberapa sanksi pidana pokok dan sanksi pidana tambahan dalam Pasal 10 KUHP masih tampak di dalamnya. Pidana kurungan adalah sanksi pidana yang dihapuskan dalam RUU KUHP. Beberapa sanksi pidana baru yang muncul dalam RUU KUHP adalah pidana pengawasan, pidana kerja sosial, pembayaran ganti rugi, serta pemenuhan kewajiban adat setempat. Salah satu jenis sanksi pidana pokok baru yang akan dibahas lebih lanjut dalam penelitian ini ialah pidana kerja sosial.

Pidana kerja sosial (community service order) merupakan sanksi pidana yang menarik untuk dikaji karena adanya kekhasan dalam sanksi pidana ini yang tidak dimiliki sanksi pidana pokok lainnya, di mana pelaku melakukan kerja sosial. Sanksi pidana ini

12 Ibid.

${ }^{13}$ Galih Puji Mulyono \& Barda Nawawi Arief, "Upaya Mengurangi Kepadatan Narapidana dalam Lembaga Pemasyarakatan di Indonesia", Jurnal Law Reform, Vol. 12, No. 1 (2016): 1-16, https://doi.org/10.14710/lr.v12i1.15838

${ }_{14}$ Rocky Marbun, "Diskursus Perumusan Ideologi sebagai Perbuatan Pidana dalam Rancangan Kitab Undang-Undang Hukum Pidana 2015". Padjajaran Jurnal Ilmu Hukum Vol. 4 No. 3 (2017): 532-550.https://doi.org/10.22304/pj̈h.v4n3.a6

15 Rancangan Undang-Undang 2019 Kitab Undang-Undang Hukum Pidana, https://www hukumonline.com/pusatdata/detail/17797/rancangan-undang-undang-2019\#! (diakses 20 Juni 2021)

16 Wamenkumham Klaim RKUHP Harapan Solusi Over Kapasitas Lapas, https://www.cnnindonesia.com/nasional/20210614132643-12-654046/wamenkumhamklaim-rkuhp-harapan-solusi-over-kapasitas-lapas (diakses 15 Juni 2021)

17 Kepala BPHN: Sudahi Pro-Kontra, Pemerintah Tampung Berbagai Masukan Terkait RUU KUHP, https://www.bphn.go.id/index.php/pubs/news/read/2021060512462233/kepala-bphnsudahi-pro-kontra-pemerintah-tampung-berbagai-masukan-terkait-ruu-kuhp (diakses 15 Juni 2021). 
adalah salah satu jenis tindakan non-penjara yang diakui dalam Resolusi Majelis Umum Persatuan Bangsa-Bangsa (PBB) Nomor 45/110 tanggal 14 Desember 1990 tentang Standard Minimum Rules for the Non-custodial Measures (Tokyo Rules). ${ }^{18}$ Tokyo Rules menekankan bahwa sanksi pidana penjara sebagai upaya terakhir, lebih diutamakan menggunakan tindakan non-penjara yang terdapat keseimbangan hak pelaku, hak korban, serta kepedulian masyarakat.19

Tokyo Rules itu sendiri adalah soft law yang tidak mengikat. Tokyo Rules sebagai salah satu instrumen internasional yang bukan berbentuk perjanjian (dapat berbentuk Pedoman/ Guidelines, Prinsip/ Principles, Deklarasi/ Declarations, Kode Praktik/ Codes of Practice, Rekomendasi/ Recommendations, atau Program/ Programmes), bertujuan untuk mempromosikan "norma-norma/ norms" yang diyakini baik. ${ }^{20}$ Oleh karena itu, Tokyo Rules bersifat umum, digunakan secara universal, serta dapat ditentukan kemudian menjadi bagian dalam perjanjian atau dianggap sebagai hukum kebiasaan internasional. 21

Tulisan terbaru mengenai sanksi pidana kerja sosial tampak dari pembahasan yang terbit pada September 2020, April 2020, dan Maret 2020. Tulisan yang terbit pada September 2020 berfokus pada analisis alasan ganti rugi serta pidana kerja soal belum digunakan pada masa sekarang serta upaya yang harus dilakukan aparat penegak hukum untuk mewujudkan tujuan pemidanaan yang berkeadilan. ${ }^{22}$ Tulisan yang terbit pada April 2020 membahas mengenai pidana kerja sosial sebagai opsi pemidanaan yang sesuai untuk penanggulangan pidana penjara. ${ }^{23}$ Tulisan yang terbit pada Maret 2020 berfokus pada korelasi di antara pidana kerja sosial dengan keadilan restoratif dan pengaturan teknis kerja sosial di Portugal, Malaysia, serta Belanda. ${ }^{24}$ Penerapan sanksi ini di Belanda juga dikatakan lebih efektif daripada pidana penjara. ${ }^{25}$

Berlandaskan pada tulisan yang terbit pada Maret 2020 di atas, maka diketahui bahwa pidana kerja sosial telah diterapkan di beberapa negara sebagai alternatif dari sanksi pidana penjara jangka pendek, sedangkan negara Indonesia baru akan menerapkannya jika RUU KUHP disahkan. ${ }^{26}$ Sanksi pidana ini sangat berkemungkinan akan sering digunakan menjadi alternatif pemidanaan daripada sanksi pidana penjara yang selalu menjadi andalan sanksi pidana di Indonesia. Catatan-catatan penting yang akan

18 United Nations Standard Minimum Rules for Non-custodial Measures (The Tokyo Rules). https://www.un.org/ruleoflaw/blog/document/united-nations-standard-minimum-rulesfor-non-custodial-measures-the-tokyo-rules/ (diakses 10 Juni 2021).

19 Ibid.

20 Anthony Aust, Handbook of Intenational Law. (UK: Cambridge University Press, 2010), 11.

${ }^{21}$ Ibid.

${ }^{22}$ Sahat Maruli Tua Situmeang, Musa Darwin Pane \& Wahyudi, “Optimalisasi Peran Penegak Hukumdalam Menerapkan Pidana Kerja Sosial dan Ganti Rugi Guna Mewujudkan Tujuan Pemidanana yang Berkeadilan", Jurnal Hukum Ius Quia Iustum, Vol 27, Iss. 3 (2020): 501-525, https://doi.org/10.20885/iustum.vol27.iss3.art4

${ }^{23}$ Asiyah Jamilah \& Hari Sutra Disemadi, "Pidana Kerja Sosial: Kebijakan Penanggulangan Overcrwoding Penjara", Jurnal IUS Kajian Hukum dan Keadilan, Vol. 8, No. 1 (2020): 26-38, http://dx.doi.org/10.29303/ius.v8i1.726

${ }^{24}$ Jamin Ginting, "Sanksi Kerja Sosial sebagai Altenatif Bentuk Pemdanaan dalam Sistem Hukum di Indonesia", Jurnal Law Review, Vol XIX, No. 3 (2020): 246-267, http://dx.doi.org/10.19166/lr.v19i3 2098

${ }_{25}$ Ibid.

26 Ibid. 
dianalisis lebih lanjut dalam penelitian ini erat kaitannya dengan Tokyo Rules dan segala tantangan dalam penggunannya di masa mendatang sehingga berbeda dengan beragam kajian yang telah ada sebelumnya. Kajian analisis penelitian ini bertujuan memberikan standar minimal dari Tokyo Rules yang harus ada pada penerapan pidana kerja sosial di kemudian hari agar siap digunakan serta tantangan-tantangan yang dimungkinkan timbul juga dapat diminimalisir. Hal tersebut akan dikaji dalam penelitian kualitatif dengan metode penelitian yuridis normatif berbentuk deksriptif analitis.

\section{Hasil dan Pembahasan}

\subsection{Pidana Kerja Sosial dalam RUU KUHP September 2019}

Ketika membicarakan mengenai sanksi pidana, dikenal tiga falsafah pemidanaan yakni retributif, relatif, dan gabungan atas keduanya. J. M. van Bemmelen berpendapat bahwa teori retributif atau teori absolut telah dikenal lama karena sejalan dengan pengalaman manusia. 27 Setiap serangan yang ditujukan pada orang lain akan memberikan reaksi balasan dari orang yang diserang tersebut. ${ }^{28}$ Hugo de Groot juga menegaskan mengenai sanksi pidana diberikan dan diterapkan karena adanya kejahatan.29 Oleh karena itu, teori ini berorientasi bahwa sanksi pidana adalah tuntutan mutlak sebagai pembalasan (let the punishment fit the crime) dan tidak berorientasi pada pelaku. ${ }^{30}$

Lalu muncul kritik atas teori absolut di atas, di mana sanksi pidana tidak boleh hanya backward looking namun juga harus forward looking agar memiliki manfaat atau tujuan bagi pelaku, korban, serta masyarakat. ${ }^{31}$ Jeremy Bentham adalah salah satu tokoh dalam aliran yang dikenal sebagai teori relatif atau teori utilitarian. Enam teori yang dapat dikatakan menjadi falsafah pemidanaan teori relatif yaitu pencegahan umum (general detterence), pencegahan khusus (specific detterence), rehabilitasi/ edukasi/ medis (rehabilitation/ education/ medical), isolasi (isolation), inkapasitasi (incapacitation), dan reintegrasi (reintegration). ${ }^{32}$

Pada perkembangan teori retributif dan teori relatif tersebut, muncul gabungan atas keduanya sebagai teori baru. J. M. van Bemmelen adalah salah satu tokoh yang berpendapat bahwa sanksi pidana memiliki tujuan membalas kejahatan, mengamankan masyarakat, serta mengembalikan pelaku kejahatan ke masyarakat. ${ }^{33}$

Sehubungan dengan falsafah pemidanaan di atas, Indonesia belum memiliki kejelasan tujuan pemidanan dalam KUHP maupun peraturan perundang-undangan di luar KUHP. Tujuan pemidanaan baru muncul dalam Pasal 51-52 RUU KUHP September 2019 yang menjadi ius constituendum. Pada tujuan pemidanaan tersebut tercermin

27 Topo Santoso, Op.Cit. h. 165.

28 Ibid.

29 Ibid.h. 166.

${ }^{30}$ Ibid.h. 166-169.

${ }^{31}$ Ibid.h. 171-172.

32 Ibid.h. 172-193.

33 Ibid. h. 194. Lihat pula Teafani Kaunang Slat, "Sanksi Pidana Kerja Sosial Terhadap Tindak Pidana Ringan Sebagai Upaya Pembaharuan Hukum Pidana Nasional", Jurnal Ilmiah Pendidikan Pancasila dan Kewarganegaraan, Vol. 4 No. 2 (2019): 352-360, http://dx.doi.org/10.17977/um019v4i2p352-360 
general prevention, rehabilitasi, special prevention, serta keseimbangan kosmos dalam hukum adat dan spiritual sesuai sila Pertama Pancasila. ${ }^{34}$ Tujuan pemidanaan itu turut melingkupi pidana kerja sosial yang kelak digunakan sebagai sanksi pidana, sehingga penting dipahami oleh aparat penegak hukum yang akan menerapkannya.

Berdasarkan bagian Penjelasan RUU KUHP diketahui bahwa pidana kerja sosial adalah salah satu alternatif dari sanksi pidana penjara. Sebagaimana pendapat dan data telah diberikan pada bagian Pendahuluan sebelumnya telah menunjukkan bahwa sanksi pidana penjara di Indonesia telah melebihi kapasitas hunian yang seharusnya di lapas. Indonesia juga penting mengikuti perkembangan sanksi pidana yang tidak hanya berfokus pada perbuatan, namun juga berorientasi pada pelaku serta masyarakat. 35

Pidana kerja sosial diartikan sebagai sanksi pidana berupa kerja sosial yang ditentukan oleh pihak berwenang agar pelaku mampu memperbaiki diri menjadi bermanfaat bagi masyarakat sekitar. ${ }^{36}$ Pidana kerja sosial memiliki tujuan rehabilitasi, di mana digunakan untuk meningkatkan kepercayaan diri pelaku melalui kinerjanya di komunitas tertentu yang bermanfaat bagi masyarakat sekitar. ${ }^{37}$ Pelaku diharapkan mampu mengembangkan tanggung jawab sosial (sekaligus peningkatan kompetensi) dan peran mereka di masyarakat akan berubah lebih baik daripada sebelumnya. ${ }^{38}$

Pada Penjelasan Pasal 65 RUU KUHP dinyatakan bahwa jenis sanksi pidana kerja sosial dilakukan agar Terpidana dibebaskan dari rasa bersalah serta masyarakat berperan secara aktif untuk memasyarakatkan Terpidana dengan melakukan hal bermanfaat dalam pidana kerja sosial. Lalu dalam Pasal 85 RUU KUHP diatur bahwa sanksi yang dapat digunakan sebagai alternatif dari sanksi pidana penjara jangka waktu tertentu yang pendek (yakni ancaman pidana kurang dari lima tahun dan hakim menjatuhkan sanksi pidana penjara paling lama enam bulan) atau sanksi pidana denda yang ringan (denda paling banyak kategori II). Oleh karena kerja sosial ini sebagai sebuah sanksi pidana, maka memberikan konsekuensi bahwa dalam pelaksanaannya, Terpidana tidak dibayar. Dengan demikian, tidak boleh ada hal bersifat komersial dalam sanksi pidana ini.

Sehubungan dengan pasal yang sama dengan di atas, pelaksanaan sanksi pidana kerja sosial disesuaikan dengan profesi Terpidana yang dapat dilakukan di lembagalembaga sosial seperti panti asuhan, rumah sakit, sekolah, ataupun panti lansia. ${ }^{39}$ Putusan pengadilan yang memberikan pidana kerja sosial harus mencantumkan:

${ }^{34}$ Tunggal S. \& Nathalina Naibaho, "Penjatuhan Kebiri Kimia bagi Pelaku Kejahatan Seksual Terhadap Anak dalam Perspektif Falsafah Pemidanaan", Jurnal Hukum \& Pembangunan, Vol. 50 No. 2 (2020):329-343, http://dx.doi.org/10.21143/ihp.vol50.no2.2594

${ }^{35}$ Shinta Rukmi, "Prospek Pidana Kerja Sosial di Indonesia", Jurnal Wacana Hukum, Vol. VII No. 1 (2008): 75-89, http:/ / dx.doi.org/10.33061/1.jwh.2008.7.1.403

${ }^{36}$ Gatot Sugiharto, "Relevansi Kebijakan Penetapan Pidana Kerja Sosial dalam Sistem Pemidanaan di Indonesia", Jurnal Novelty, Vol. 7 No. 1 (2016): 83-96, http://dx.doi.org/10.26555/novelty.v7i3.a3936

${ }^{37}$ Eoin Guifolye, "What Exactly is a Community Service Order in Ireland?", Irish Probation Journal, Vol 14 (2017): 189-205, http://www.probation.ie/en/PB/Pages/WP17000058

38 Ibid.

${ }^{39}$ Iskandar Wibawa, "Pidana Kerja Sosial Dan Restitusi Sebagai Alternatif Pidana Penjara dalam Pembaharuan Hukum Pidana Indonesia", Jumal Media Hukum, Vol. 24, No. 2 (2017: 105-114), https://doi.org/10.18196/jmh.2017.0086.105-114 
- jangka waktu pidana penjara atau besarnya denda yang diberikan oleh hakim.

- jangka waktu pidana kerja sosial yang ditentukan (jumlah jam per hari dan jangka waktu penyelesaian pidana kerja sosial). Ketentuan waktu yang diatur ialah paling singkat 8 (delapan) jam dan paling lama 240 (dua ratus empat puluh) jam yang dilaksanakan paling lama delapan jam sehari. Keberlakuannya dapat diangsur paling lama 6 (enam) bulan dengan memperhatikan kegiatan Terpidana dalam menjalankan pekerjaannya dan/atau kegiatan lainnya.

- sanksi jika terpidana tidak menjalani pidana kerja sosial yang dijatuhkan (sebagian atau seluruhnya tanpa alasan sah). Sanksi tersebut dapat berupa:

“a. mengulangi seluruh atau sebagian pidana kerja sosial tersebut;

b. menjalani seluruh atau sebagian pidana penjara yang diganti dengan pidana kerja sosial tersebut; atau

c. membayar seluruh atau sebagian pidana denda yang diganti dengan pidana kerja sosial atau menjalani pidana penjara sebagai pengganti pidana denda yang tidak dibayar."

Pelaksanaan pidana kerja sosial bagi Terpidana adalah kewenangan Jaksa. Proses pembimbingan dilakukan pembimbing kemasyarakatan yang dapat bekerja sama dengan lembaga pemerintah yang membidangi pekerjaan sosial (Penjelasan Pasal 85 ayat (8) RUU KUHP).

Hakim dalam memberikan sanksi pidana kerja sosial harus mempertimbangkan beberapa hal dalam diri pelaku dalam Pasal 85 ayat (2) RUU KUHP yakni pengakuannya atas tindak pidana yang dilakukan, kemampuan kerjanya, persetujuannya sesudah dijelaskan mengenai tujuan dan segala hal yang berhubungan dengan pidana kerja sosial, riwayat sosialnya, perlindungan keselamatan kerjanya, keyakinan agama dan politiknya; dan kemampuannya membayar pidana denda. Hal terakhir yang disebutkan penting dipertimbangkan Hakim karena sanksi pidana kerja sosial adalah alternatif dari pidana denda bagi yang tidak mampu membayar.

Persetujuan Terdakwa setelah dijelaskan mengenai pidana kerja sosial sebagai pertimbangan bagi Hakim karena diamanatkan dalam Convention for the Protection of Human Rights and Fundamental Freedom (tidak diratifikasi karena terbatas pada wilayah Eropa saja, namun merupakan konvensi yang memberikan perlindungan hak asasi manusia dan kebebasan fundamental) dan International Covenant on Civil and Political Rights (diratifikasi Indonesia melalui Undang-Undang Nomor 12 Tahun 2005 Tentang Pengesahan ICCPR/ Kovenan Internasional Tentang Hak-Hak Sipil dan Politik).

Persetujuan di antara pelaku dan Hakim memang tidak lazim dalam konteks pemidanaan, namun hal ini dimaknai agar kerja sosial yang dilakukan bukan menjadi kerja paksa yang melanggar hak asasi dari pelaku. ${ }^{40}$ Persetujuan ini juga bukan berarti menjadi kesepakatan dalam bidang perdata yang menghilangkan esensi dari tujuan

${ }^{40}$ J. Remmelink, Pengantar Hukum Pidana Material 3: Terjemahan dari Inleiding Tot De Studie Van Het Nederlandse Strafrecht, (Yogyakarta: Maharsa, 2017), 45. 
pemidanaan. Persetujuan ini juga menjadi jaminan bagi Hakim bahwa pelaku termotivasi untuk melakukan kerja sosial.41

Itulah mengapa Jaksa Penuntut Umum dan Hakim yang kelak memilih menggunakan sanksi pidana kerja sosial kepada pelaku harus memahami tujuan pemidanaan yang diikuti dengan pedoman pemidanaan (Pasal 53-56 RUU KUHP), pedoman penerapan pidana penjara dengan perumusan tunggal dan perumusan alternatif (Pasal 57 RUU KUHP), pemberatan pidana (Pasal 58-59 RUU KUHP), serta ketentuan lain tentang pemidanaan (Pasal 60-63 RUU KUHP) yang relevan dengan kerja sosial sebagai batasan yang terukur dalam penggunaannya sebagai sanksi pidana.

\subsection{Tinjauan Tokyo Rules sebagai Instrumen Internasional Non-Penjara dan Pidana Kerja Sosial}

Tokyo Rules adalah salah satu standar/ pedoman minimal untuk sanksi berbentuk nonpenjara yang diterbitkan PBB tahun 1990 berdasarkan Resolusi Majelis Umum PBB Nomor 45/110 tanggal 14 Desember 1990.42 Majelis Umum terdiri dari semua Anggota Perserikatan Bangsa-Bangsa, masing-masing memiliki satu suara. ${ }^{43}$ Majelis Umum PBB tidak memiliki kekuasaan legislatif, sehingga produk yang dihasilkannya (termasuk Tokyo Rules) pada dasarnya hanya rekomendasi. ${ }^{44}$ Seiring waktu substansi dari rekomendasi dalam suatu Resolusi Majelis Umum PBB dapat diterima sebagai hukum kebiasaan internasional serta dalam kasus-kasus khusus tertentu, mereka juga dapat mempunyai akibat hukum. ${ }^{45}$

Tokyo Rules adalah rekomendasi yang telah diterima sebagai bagian dari hukum kebiasaan internasional. Hal ini dapat dilihat dari penggunaan Tokyo Rules dalam United Nations Rules for the Treatment of Women Prisoners and Non-custodial Measures for Women Offenders (Bangkok Rules) yang diterbitkan sebagai Resolusi Majelis Umum PBB Desember 2010 serta United Nations Standard Minimum Rules for the Treatment of Prisoners (the Nelson Mandela Rules) yang diterbitkan sebagai Resolusi Majelis Umum PBB Desember 2015.

Selain itu, Tokyo Rules juga telah digunakan beragam wilayah di dunia, pada tahapantahapan sistem peradilan pidana. ${ }^{46}$ Beberapa di antaranya adalah New Zealand, Jerman, Costa Rica, Inggris \& Wales, Malawi, Ghana, El Savador, Uruguay, Kazakhstan, Nigeria. ${ }^{47}$ Penerapan Tokyo Rules bervariasi di seluruh dunia dan

\footnotetext{
${ }^{41}$ Gatot Sugiharto, Op.Cit., 91.

42 United Nations Standard Minimum Rules for Non-custodial Measures (The Tokyo Rules), Op.Cit.

${ }^{43}$ Anthony Aust, Op.Cit., 190.

${ }^{44}$ Ibid.

${ }^{45}$ Ibid. Lihat A. Leovaldi Tirta, "Kekuatan Resolusi Majaleis Umum PBB (UNGA) dan Dewan Keamanan PBB (UNSC) sebagai Sumber Hukum Internasional”, Jurnal Yustika, Vol. 14 No. 1 (2011): 93-107, https:/ /joumal.ubaya.ac.id/index.php/yustika/article/view/1450

46 United Nations Asia and Far East Institute for the Prevention of Crime and the Treatment of Offenders (UNAFEI), Report of The Seminar: The 25th Anniversary Seminar of The United Nations Standard Minimum Rules for Non-Custodial Measures, 7-9 September 2015, 2.

${ }^{47}$ Ibid.
} 
memberikan alternatif positif untuk sanksi pidana penjara. ${ }^{48}$ Khusus mengenai pidana kerja sosial telah berhasil dilakukan di Zimbabwe, Swedia, Kenya. ${ }^{49}$

Minoura Satoshi berpendapat bahwa Tokyo Rules dalam wilayah Asia dapat dilihat dalam tiga klasifikasi.50 Klasifikasi pertama ialah negara dengan kerangka hukum yang diimplementasikan secara baik seperti Jepang, Filiphina, Singapura, Korea Selatan, dan Thailand.51 Klaifikasi kedua adalah negara yang memperbolehkan banyak sanksi nonpenjara tetapi kurang dalam implementasinya seperti Brunei, Indonesia, Malaysia, Myanmar, dan Vietnam.52 Klasifikasi ketiga yakni negara dengan beberapa sanksi nonpenjara yang diimplementasi seperti Kamboja dan Laos. ${ }^{53}$

PBB melalui Tokyo Rules bermaksud menyatakan bahwa sanksi non-penjara yang efektif dapat mengurangi situasi jumlah hunian lapas yang berlebih dari kapasitas seharusnya. ${ }^{54}$ Tujuan umum dari pemberian sanksi non-penjara ialah adanya alternatif sanksi efektif bagi pelaku tindak pidana (individualizing sentencing) serta aparat penegak hukum berkemungkinan memberi sanksi pidana yang memperhatikan kepentingan pelaku (untuk tetap belajar, berinteraksi dengan orang lain, maupun bekerja) sesuai perbuatan jahat yang telah dilakukannya. ${ }^{55}$

Sanksi non-penjara memiliki kekhasan sebagai prevensi bagi masyarakat dari tindak pidana dan sebagai represi bagi pelaku untuk dihukum secara fair serta diperhatikan hak-haknya. 56 Tujuan utamanya ialah melawan tindak pidana tanpa harus memberikan sanksi pidana penjara (tanpa pembatasan kemerdekaan pelaku/ insolation measures). ${ }^{57}$ Beberapa manfaat pemberian sanksi non-penjara antara lain:58

a. Perlindungan non-penjara bagi pelaku yang tindak pidananya tergolong ringan maupun pelaku yang membutuhkan bantuan medis, psikiatrik, atau sosial;

b. Kecil kemungkinan pelaku mengulangi tindak pidana (residivis);

c. Berpotensi mengurangi keuangan negara dalam pengelolaan penjara;

d. Dampak positif bagi pelaku yang tidak terbatas kemerdekaannya dengan penjara sehingga pelaku dapat berubah lebih baik dalam kondisi normal yang alami (tidak ada stigmatisasi);

e. Tingginya kemungkinan reintegrasi yang lebih baik bagi pelaku tindak pidana ke masyarakat;

${ }^{48} \mathrm{Ibid}$.

${ }^{49} \mathrm{Ibid}$

${ }^{50}$ Ibid, h. 3-4.

51 Ibid.

52 Ibid.

53 Ibid.

${ }^{54}$ Erasmus A. T. Napitupulu., et. al, Hukuman Tanpa Penjara: Pengaturan, Pelaksanaan, dan Proyeksi Alternatif Pemidanaan Non Pemenjaraan di Indonesia. (Jakarta: Institute for Criminal Justice Reform, 2019), 4.

${ }^{55} \mathrm{Ibid}$.

${ }^{56}$ Ibid, 15. Lihat Adrian Leka. "Comparative Overview of Alternative Measures in Different Places", Academic Journal of Interdisciplinary Studies, Vol. 3 No. 4 (2014): 219-223, http://dx.doi.org/10.5901/ajis.2014.v3n4p219

57 Ibid.h. 17.

58 Ibid.h. 15. 
f. Keterlibatan masyarakat secara aktif yang membantu penerimaan publik dalam proses perubahan diri pelaku tindak pidana.

Ditegaskan pada ketentuan 2.3 Tokyo Rules bahwa sanksi non-penjara pada tataran lebih operasional dalam sistem peradilan pidana harus tersedia sejak sebelum proses persidangan hingga setelah adanya putusan hakim untuk memberi ruang dinamis yang sesuai dengan sifat dan asal tindak pidana, latar belakang pelaku, perlindungan bagi masyarakat, dan menghindari pidana penjara yang tidak diperlukan. Ketentuan 2.7 Tokyo Rules menegaskan bahwa penggunaan sanksi non-penjara harus menjadi gerakan menuju depenalisasi dan dekriminalisasi.

Berlandaskan pada ketentuan 8 Tokyo Rules mengenai pemidanaan terdapat beragam alternatif sanksi non-penjara. Salah satu di antaranya ialah a community service order atau yang dikenal juga sebagai pidana kerja sosial. Mengingat bahwa Tokyo Rules adalah aturan standar atau pedoman sanksi non-penjara (di dalamnya termasuk pidana kerja sosial), maka kajian berikut ini adalah beberapa hal penting untuk diperhatikan sebagai pedoman/ standar dalam pengaturan maupun penggunaan pidana kerja sosial di Indonesia pada masa mendatang berdasarkan Tokyo Rules: 59

1) Penggunaannya sesuai pertimbangan masing-masing negara mengenai (ketentuan 1.3 dan 1.4):

- politik, ekonomi, sosial, budaya;

- tujuan dan maksud sistem peradilan pidana;

- keseimbangan di antara hak-hak pelaku, korban, masyarakat, serta keselamatan publik dan pencegahan tindak pidana.

2) Tidak adanya diskriminasi atas dasar ras, warna kulit, jenis kelamin, usia, bahasa, agama, politik, pendapat berbeda, kebangsaan/ asal-usul sosial, properti, kelahiran, atau status lainnya (ketentuan 2.2).

3) Dikembangkannya harus didorong dengan pemantauan secara ketat serta penggunaan yang dievaluasi secara sistematis dengan prinsip intervensi minimal (ketentuan 2.4).

4) Pengenalan, definisi, dan penerapannya ditentukan dalam hukum serta penggunaan didasarkan pada penilaian kriteria yang ditetapkan sesuai sifat dan beratnya tindak pidana, kepribadian dan latar belakang pelaku, tujuan pemidanaan, dan hak-hak korban (ketentuan 3.2).

5) Diskresi yudisial atau otoritas lain yang berwenang harus dilakukan di semua tahap proses dengan memastikan adanya akuntabilitas penuh dan sesuai dengan aturan hukum (ketentuan 3.3).

6) Karena adanya kewajiban memaksa bagi pelaku, maka sebelum diterapkan akan membutuhkan persetujuan pelaku (ketentuan 3.4).

7) Catatan pribadi pelaku harus dijaga kerahasiaannya dan tertutup bagi akses pihak ketiga dan bersifat terbatas bagi pihak yang berkaitan langsung dengan disposisi kasus pelaku atau pihak berwenang lainnya (ketentuan 3.21).

${ }^{59}$ United Nations Standard Minimum Rules for Non-custodial Measures (The Tokyo Rules), Op.Cit. 
8) Pada tahapan "trial and sentencing" dimungkinkan adanya social inquiry reports yang dilakukan oleh otoritas peradilan independen. Laporan ini berisi informasi sosial dari pelaku yang relevan dengan pola pelanggarannya, tindak pidana yang dilakukan saat ini, informasi, dan rekomendasi yang relevan dengan prosedur pemidanaan. Laporan ini harus faktual, objektif, tidak memihak, dengan beragam bentuk pendapat yang teridentifikasi dengan jelas (ketentuan 7.1).

9) Jika sanksi pidana kerja sosial membutuhkan pengawasan, maka harus dilakukan oleh pejabat berwenang berdasarkan hukum serta dilakukan secara berkala agar pelaku dapat mengatasi pelanggarannya (ketentuan 10.2-10.3). Pengawasan dilakukan untuk mengurangi pengulangan tindak pidana dan membantu integrasi pelaku ke masyarakat dengan cara yang meminimalkan kemungkinan tindak pidana terjadi kembali (ketentuan 10.1).

10) Apabila diperlukan, pelaku dapat diberikan psikologis sosial, bantuan materi, dan kesempatan untuk memperkuat hubungannya dengan masyarakat dan memfasilitasi reintegrasi pelaku (ketentuan 10.4).

11) Jangka waktu sanksi pidana kerja sosial tidak boleh melebihi periode yang ditetapkan pejabat berwenang sesuai hukum dan dapat ditentukan penghentian dini jika pelaku melakukannya dengan baik (ketentuan 11.111.2).

12) Pelaku pada awal penerapan sanksi pidana kerja sosial harus menerima penjelasannya secara lisan dan tertulis, termasuk kewajiban dan hak pelaku (ketentuan 12.3). Kondisi lain dapat diubah oleh pejabat berwenang sesuai dengan hukum dan kemajuan yang dicapai pelaku (ketentuan 12.4).

13) Pelanggaran pelaku atas sanksi pidana kerja sosial yang telah ditentukan dapat berakibat pada modifikasi atau pencabutan sanksi tersebut yang dilakukan oleh pejabat berwenang berdasarkan hukum (setelah adanya pemeriksaan fakta secara hati-hati dengan petugas pengawas) serta dapat dilakukan banding ke pengadilan atau pejabat lain yang berwenang secara independen. Kegagalan tersebut tidak secara otomatis mengakibatkan pemberian sanksi penjara karena pidana penjara hanya diberikan jika tidak ada alternatif lain yang sesuai. (ketentuan 14.1-14.6)

14) Tidak boleh ada diskriminasi dalam perekrutan staf dan harus mempertimbangkan kebijakan nasional tindakan afirmatif dan mencerminkan keragaman pelaku yang akan diawasi. Adanya kualifikasi staf yang harus ditentukan jelas. Bagi staf professional yang memenuhi syarat harus disediakan pengembangan karir (termasuk gaji, tunjangan memadai sesuai difat pekerjaan yang dilakukan). (ketentuan 15.1-15.2)

15) Ketika pelatihan, staf harus dijelaskan mengenai tanggung jawab yang perlu bekerjasama dan mengkoordinasikan kegiatan dengan beragam instansi dalam rangka merehabilitasi pelaku, menjamin hak-hak pelaku, dan melindungi masyarakat. Pelatihan harus mencakup pula instruksi sanksi pidana kerja sosial, tujuannya, dan penerapannya. Setelah resmi bertugas, staf harus memelihara dan meningkatkan pengetahuan serta 
kapasitas professional dengan mengikuti pelatihan-pelatihan. Fasilitas harus disediakan untuk mencapai kesemuanya. (ketentuan 16.1-16.3)

16) Partisipasi publik harus didorong karena menjadi sumber daya utama dan salah satu faktor terpenting dalam meningkatkan ikatan antara pelaku, keluarga, dan masyarakat. Hal itu seharusnya untuk melengkapi sistem peradilan pidana dan untuk menjadi kesempatan anggota masyarakat berkontribusi melindungi masyarakat itu sendiri. (ketentuan 17.1-17.2)

17) Instansi pemerintah, sektor swasta, dan masyarakat umum harus didorong untuk mendukung organisasi yang mendukung pidana kerja sosial. Konferensi, seminar, simposium, dan kegiatan lain harus diselenggarakan secara teratur untuk merangsang kesadaran akan perlunya partisipasi masyarakat dalam penerapan pidana kerja sosial. Segala bentuk media massa (setiap upaya) harus dimanfaatkan untuk membantu menciptakan sikap publik yang mengarah ke kegiatan kondusif untuk aplikasi yang lebih luas pidana kerja sosial dan integrasi sosial bagi pelaku. (ketentuan 18.118.4)

18) Bagian penting dari perencaan adalah upaya untuk melibatkan badan publik dan swasta dalam organisasi serta penelitian sanksi pidana kerja sosial bagi pelaku. Penelitian tentang masalah yang dihadapi pelaku, praktisi, masyarakat, dan pembuat kebijakan harus dilakukan secara teratur. Mekanisme penelitian dan informasi harus dibangun dalam sistem peradilan pidana untuk pengumpulan dan analisis data serta statistik pelaksanaan pidana kerja sosial bagi pelaku. (ketentuan 20.1-20.3)

19) Program pidana kerja sosial harus direncanakan secara sistematis dan dilaksanakan sebagai bagian integral dari sistem peradilan pidana dalam proses pembangunan nasional. Evalasi rutin harus dilakukan dengan tuuan untuk mengimplementasikan pidana kerja sosial lebih efektif. Tinjaun berkala harus dilakukan untuk menilai tujuan, fungsi, dan efektivitas pidana kerja sosial. (ketentuan 21.1-21.3)

20) Mekanisme yang sesuai harus dikembangkan pada berbagai tingkat untuk memfasilitasi pembentukan hubungan antara layanan yang bertanggung jawab untuk pidana kerja sosial, baik pemerintah maupun non-pemerintah di bidang-bidang seperti kesehatan, perumahan, pendidikan dan tenaga kerja, dan media massa. (ketentuan 22.1)

21) Upaya harus dilakukan untuk memajukan kerjasama ilmiah antar negara dalam hal penelitian, pelatihan, bantuan teknis, dan pertukaran informasi di antara negara-negara anggota tentang langkah-langkah yang harus diperkuat dalam hal pidana kerja sosial. Melalui lembaga-lembaga PBB untuk pencegahan kejahatan dan perlakuan terhadap pelaku, kerja sama dengan the Crime Prevention and Criminal Justice Branch of the Centre for Social Development dan Humanitarian Affairs of the United Nations Secretariat. (ketentuan 23.1)

22) Studi banding dan harmonisasi ketentuan perundang-undangan harus dilanjutkan untuk memperluas jangkauan opsi non-institusional dan memfasilitasi penerapannya melintasi batas-batas nasional, sesuai dengan 
Model Treaty on the Transfer of Supervision of Offenders Conditionally Sentenced or Conditionally Released. (ketentuan 23.2)

Kedua puluh dua hal di atas adalah standar atau pedoman dari Tokyo Rules yang minimal ada untuk menerapkan sanksi non-penjara, termasuk sanksi pidana kerja sosial. Melihat pada ketentuan Pasal 65-66 serta Pasal 85 RUU KUHP terkait pidana kerja sosial yang dihubungkan dengan kedua puluh dua hal tersebut, maka tampak hanya tujuh hal yang telah diatur secara umum dalam RUU KUHP (poin a, d, f, i, k, l, $\mathrm{m})$ dan banyak hal lainnya yang belum muncul.

Ketentuan Penutup dalam Pasal 625 RUU KUHP mensyaratkan mengenai "Peraturan pelaksanaan dari Undang-Undang ini harus ditetapkan paling lama 2 (dua) tahun sejak Undang-Undang ini diundangkan" serta Pasal 628 RUU KUHP mensyaratkan mengenai "Undang-Undang ini mulai berlaku 2 (dua) tahun terhitung sejak tanggal diundangkan". Keduanya dapat ditafsirkan bahwa pada jangka waktu 2 (dua) tahun setelah tanggal RUU KUHP diundangkan, maka segala ketentuan di dalamnya akan mulai berlaku serta harus ada peraturan pelaksanaannya.

Peraturan pelaksana yang dimaknai dalam Ketentuan Penutup RUU KUHP haruslah mencakup hingga pengaturan lebih lanjut ketentuan pidana kerja sosial sebagai sanksi pidana baru. Hal itu penting karena mengingat banyak hal dari kedua puluh dua hal Tokyo Rules yang disyaratkan sebagai standar minimal untuk sanksi pidana kerja sosial belum muncul dalam RUU KUHP. Peraturan pelaksana yang dimaksudkan dapat berupa Peraturan Pemerintah tentang Tata Cara Pelaksanaan Sanksi Pidana Kerja Sosial. Oleh karena itu, Peraturan Pemerintah yang akan dibuat di masa mendatang penting mempertimbangkan korelasi kedua puluh dua hal Tokyo Rules yang telah disebutkan di atas dengan negara Indonesia dan kemudian mengaturnya secara matang agar dapat diimplementasikan oleh para pihak yang terlibat di dalamnya.

\subsection{Wacana Tantangan Pidana Kerja Sosial di Indonesia}

Pidana kerja sosial sudah sejak tahun 1973 berlaku di Inggris dengan istilah Community Service Order. ${ }^{60}$ Negara Belanda mengenal pidana kerja sosial sejak tahun 1961 dan dilakukan di lingkungan swasta ataupun pemerintah yang berhubungan dengan bidang sosial. 61 Kemudian berkembang di negara-negara seperti Amerika, Italia, Jerman, dan lainnya dengan wujud pidana kerja sosial yang membutuhkan penentuan program yang memiliki perencanaan matang, kreativitas, cermat dalam penempatannya, serta didukung dengan kebutuhan dari komunitas. ${ }^{62}$ Berikut adalah contoh wujud pidana kerja sosial yang dimaksudkan:63

- Bend, Oregon dengan berkontribusi aktif (mengajak rekan lain beramal maupun mempromosikan acara ke lingkungan sekitar) untuk

${ }^{60}$ J. Remmelink, Op.Cit., 41.

${ }_{61}$ Jamin Ginting, Op.Cit., 255.

${ }^{62}$ Asiyah Jamilah \& Hari Sutra Disemadi, Op.Cit., 30.

63 Gordon Bazemore \& Dennis Maloney, "Rehabilitating Community Service: Toward Restorative Service Sanctions in a Balanced Justice System", Federal Probation, Vol. 58 Iss. 1. (1994):

24-35, https://heinonline.org/HOL/LandingPage?handle=hein.journals/fedpro58\&div=8\&id=\&pa

$\mathrm{ge}=$ 
mengumpulkan makanan, pakaian, serta membiayai pembangunan unit penampungan bagi keluarga tunawisma pada musim dingin;

- Minnesota Selatan dengan membangun tempat perlindungan, menyingkirkan pohon tumbang, membantu mencari reruntuhan barang akibat bencana tornado.

Diketahui pula wujud lainnya dapat berupa pengarsipan untuk penugasan di dalam kantor, memungut sampah, membersihkan toilet, membantu lansia ataupun anak-anak di sekolah luar biasa, atau layanan sosial lainnya. ${ }^{64}$

Lalu pengawasan sanksi pidana kerja sosial di Belanda dilakukan oleh tiim khhusus melalui elektronik berbasis teknologi Global Positioning System (GPS). ${ }^{65}$ Sedangkan pengawasan sanksi ini di Malaysia dilakukan dengan membentuk satuan tugas dari Kementerian Sosial serta Kementerian Perempuan dan Keluarga. ${ }^{66}$

Pengaturan lebih lanjut pelaksanaan sanksi pidana kerja sosial di Indonesia merupakan hal utama dalam mencapai keberhasilan terkait pembinaan hubungan di antara pelaku dengan masyarakat untuk mengembangkan empati yang lebih peka dengan lingkungan atau orang lain di sekitarnya (serta agar sejalan dengan tujuan pemidanaan dalam Pasal 51-51 RUU KUHP). Pemenuhan kedua puluh dua standar minimal Tokyo Rules yang disesuaikan dengan situasi negara Indonesia adalah hal penting. Bagaimana kriteria serta perekrutan staf yang bertanggung jawab; bagaimana pelatihan berkelanjutan serta hak-hak bagi staf; bagaimana koordinasi antarlembaga, antarpribadi, antaranggota masyarakat; bagaimana bentuk pengawasan; bagaimana evaluasi kinerja pelaksanaan sanksi pidana kerja sosial; serta pertanyaan lainnya yang terkait kedua puluh dua standar minimal Tokyo Rules harus ditindaklanjuti secara matang. Faktor-faktor penting untuk diperhatikan sebagai tantangan dalam penerapan sanksi pidana kerja sosial ialah antara lain (1) ketersediaan pekerjaan sosial bagi para pelaku dengan pengawasan ketat yang tepat, (2) pelaku melakukan pekerjaan yang diwajibkan dan ia tidak dieksploitasi dengan cara apapun, (3) perlu adanya mekanisme kerjasama efektif di antara pengadilan, lembaga yang memberikan pekerjaan sosial, serta badan yang bertanggung jawab dalam pengawasan, (4) perlu ada staf/ sumber daya manusia, tempat, dana yang memadai. ${ }^{67}$

Pembahasan staf/ sumber daya manusia memadai dalam pelaksanaan pidana kerja sosial dapat dibayangkan akan berhubungan dengan petugas pembimbing kemasyarakatan berdasarkan Pasal 85 RUU KUHP. Petugas tersebut apabila merujuk pada aturan Pemasyarakatan (Undang-Undang Nomor 12 Tahun 1995 dan Keputusan Menteri No M.01.PR.07.03 Tahun 1997), maka mereka yang dimaksudkan adalah Pembimbing Kemasyarakatan yang terdapat di Balai Pemasyarakatan (Bapas). Saat ini Pembimbing Kemasyarakatan bertugas melakukan penelitian kemasyarakatan, pembimbingan, pendampingan serta pengawasan pada Klien Pemasyarakatan anak maupun dewasa (Peraturan Pemerintah Nomor 31 Tahun 1999 dan Permenkumham Nomor 35 Tahun 2018). Mengingat jumlah Narapidana yang berlebih di bagian Pendahuluan penelitian ini serta jumlah Pembimbing Kemasyarakatan yang

\footnotetext{
${ }^{64} \mathrm{Ibid}$.

65 Jamin Ginting, Op.Cit., 257.

${ }^{66}$ Ibid., 262.

67 UNODC-ICRC, Handbook on Strategies to Reduce Overcrowding in Prisons: Criminal Justice Handbook Series, (Vienna: United Nations, 2013), 119.
} 
bermasalah di tahun 202068, maka harus dipertimbangkan secara bijak bagi pihak yang akan bertanggung jawab mengenai pembimbingan dalam pidana kerja sosial adalah Pembimbing Kemasyarakatan.69

Sub-divisi baru dari Bapas yang khusus berfokus pada sanksi pidana kerja sosial dan berbeda dengan sanksi pidana penjara adalah jalan terbaik. Hal tersebut berlandaskan pada karakteristik pidana kerja sosial (dalam hal pelaksanaan, pengawasan, evaluasi; pemahaman makna sanksi, tujuannya bagi Terpidana, pihak-pihak relevan, serta masyarakat sekitar) yang membutuhkan sejumlah sumber daya manusia dengan pengetahuan dan kemampuan baru untuk melaksanakan pengawasan ketat bagi Terpidana kerja sosial.

Tantangan lain yang dapat terjadi ialah pemberian stigma negatif dari masyarakat (labeling) kepada Terpidana kerja sosial. Sebagaimana diketahui sebelumnya bahwa pelaksanaan sanksi pidana kerja sosial disesuaikan dengan profesi Terpidana yang dapat dilakukan di lembaga-lembaga sosial seperti panti asuhan, rumah sakit, sekolah, ataupun panti lansia. Mengubah stigma negatif masyarakat atas Terpidana penjara tidak mudah karena tidak ada wujud nyata sisi sosial yang dilakukannya, terkecuali pada masa asimilasi yang begitu singkat. Akan tetapi, bagi Terpidana kerja sosial seharusnya hal tersebut dapat dihindari. Terpidana kerja sosial yang melakukan kewajiban kerja sosialnya secara berkelanjutan sesuai yang telah ditentukan adalah wujud nyata dari pelaku bahwa ia berkeinginan untuk berubah lebih baik dan bermanfaat bagi masyarakat sekitar. Oleh karena itu, dengan perencanaan lokasi dan jangka waktu kerja sosial yang dilakukan pelaku secara tepat serta sosialisasi pidana kerja sosial kepada masyarakat Indonesia, maka manfaat dari kerja sosial yang pelaku lakukan dapat mengurangi atau menghilangkan stigma negatif dari masyarakat.

\section{Kesimpulan}

Pemberlakuan sanksi pidana kerja sosial di Indonesia pada masa mendatang sangat membutuhkan perencanaan matang dalam sisi regulasi agar kelak dapat diterapkan dengan efektif dan bermanfaat. Pidana kerja sosial sebagai sanksi pidana non-penjara berkaitan erat dengan Tokyo Rules. Kedua puluh dua hal dalam Tokyo Rules harus dikembangkan lebih lanjut secara matang dalam peraturan pelaksana (berupa Peraturan Pemerintah tentang Tata Cara Pelaksanaan Sanksi Pidana Kerja Sosial) sebagai standar minimal penggunaan sanksi pidana kerja sosial di Indonesia. Hal tersebut penting dilakukan karena pengaturan pidana kerja sosial di RUU KUHP masih bersifat umum serta agar tantangan-tantangan yang mungkin terjadi dapat diminimalisir dalam pelaksanaan pidana kerja sosial di masa mendatang.

Setelah adanya peraturan pelaksana pidana kerja sosial yang dibentuk dalam kurun waktu 2 (dua) tahun setelah KUHP terbaru disahkan, maka dalam pelaksanaannya juga harus dengan memahami tujuan pemidanaan yang diikuti dengan pedoman pemidanaan (Pasal 53-56 RUU KUHP), pedoman penerapan pidana penjara dengan

68 Ombudsman Temukan Rupbasan dan Bapas Bermasalah, https://ombudsman.go.id/news/r/ombudsman-temukan-rupbasan-dan-bapas-bermasalah (diakses 14 Juni 2021)

${ }^{69}$ Lihat Trisapto Wahyudi Agung Nugroho. "Analisa Kebutuhan Pembimbing Kemasyarakatan Balai Pemasyarakatan (Bapas) Bandung", Jurnal Ilmiah Kebijakan Hukum, Vol. 13 No.1 (2019), h. 69-84, http://dx.doi.org/10.30641/ kebijakan.2019.V13.69-84 
perumusan tunggal dan perumusan alternatif (Pasal 57 RUU KUHP), pemberatan pidana (Pasal 58-59 RUU KUHP), serta ketentuan lain tentang pemidanaan (Pasal 60-63 RUU KUHP).

Setelah kesemuanya dilakukan, semoga kelak pidana kerja sosial (sebagai sanksi alternatif dari pidana penjara) memberikan bermanfaat maksimal bagi pelaku dan masyarakat sekitar di Indonesia.

\section{Ucapan terima Kasih (Acknowledgments)}

Terima kasih kepada Fakultas Hukum Universitas Udayana, para narasumber, para peserta lain dalam kegiatan Call for Paper "Pidana dan Pemidanaan dalam RUU KUHP" yang terselenggara pada 26 Juni 2021 serta semua pihak yang berperan dalam penulisan artikel ini.

\section{Daftar Pustaka}

\section{Buku}

Akbari, Anugrah Rizki. Potret Kriminalisasi Pasca Reformasi dan Urgensi Reklasifikasi Tindak Pidana di Indonesia. Jakarta: Institute for Criminal Justice Reform, 2015.

Aust, Anthony. Handbook of Intenational Law, UK: Cambridge University Press, 2010.

Napitupulu, Erasmus A. T., et. al. Hukuman Tanpa Penjara: Pengaturan, Pelaksanaan, dan Proyeksi Alternatif Pemidanaan Non Pemenjaraan di Indonesia, Jakarta: Institute for Criminal Justice Reform, 2019.

Remmelink, J. Pengantar Hukum Pidana Material 3: Terjemahan dari Inleiding Tot De Studie Van Het Nederlandse Strafrecht, Yogyakarta: Maharsa, 2017.

Santoso, Topo. Hukum Pidana Suatu Pengantar, Depok: PT RajaGrafindo Persada, 2020.

UNODC-ICRC, Handbook on Strategies to Reduce Overcrowding in Prisons: Criminal Justice Handbook Series, Vienna: United Nations, 2013.

\section{Jurnal}

Bazemore, Gordon \& Dennis Maloney, "Rehabilitating Community Service: Toward Restorative Service Sanctions in a Balanced Justice System", Federal Probation, $\begin{array}{lllll}\text { Vol. } & 58 & \text { Iss. } & \text { 24-35, }\end{array}$ https: / /heinonline.org/HOL/LandingPage?handle=hein.journals/fedpro58\&di $\mathrm{v}=8$ \&id $=$ \& page $=$

Ginting, Jamin, “Sanksi Kerja Sosial sebagai Altenatif Bentuk Pemdanaan dalam Sistem Hukum di Indonesia", Jurnal Law Review, Vol XIX, No. 3 (2020): 246-267. http://dx.doi.org/10.19166/lr.v19i3.2098

Guifolye, Eoin, "What Exactly is a Community Service Order in Ireland?", Irish Probation Journal, Vol $14 \quad$ (2017): http://www.probation.ie/en/PB/Pages/WP17000058

Imandeka, Ejo \& Zulfikri, "Preventing Coronavirus in Overcrowded Prisons in Indonesia", Proceedings of the 1st International Conference on Law and Human Rights 2020 (ICLHR 2020) dalam Advances in Social Science, Education and $\begin{array}{lllll}\text { Humanities } & \text { Research } & \text { vol. } & 549 & \text { (2020): }\end{array}$ https://dx.doi.org/10.2991/assehr.k.210506.022 
Jamilah, Asiyah \& Hari Sutra Disemadi, "Pidana Kerja Sosial: Kebijakan Penanggulangan Overcrwoding Penjara", Jurnal IUS Kajian Hukum dan Keadilan, Vol. 8, No. 1 (2020): 26-38. http://dx.doi.org/10.29303/ius.v8i1.726

Leka, Adrian. "Comparative Overview of Alternative Measures in Different Places", Academic Journal of Interdisciplinary Studies, Vol. 3 No. 4 (2014): 219-223. http://dx.doi.org/10.5901/ajis.2014.v3n4p219

Marbun, Rocky. "Diskursus Perumusan Ideologi sebagai Perbuatan Pidana dalam Rancangan Kitab Undang-Undang Hukum Pidana 2015". Padjajaran Jurnal Ilmu Hukum Vol. 4 No. 3 (2017): 532-550, https:// doi.org/10.22304/pjih.v4n3.a6

Mulyono, Galih Puji \& Barda Nawawi Arief, “Upaya Mengurangi Kepadatan Narapidana dalam Lembaga Pemasyarakatan di Indonesia", Jurnal Law Reform, Vol. 12, No. 1 (2016): 1-16, https://doi.org/10.14710/lr.v12i1.15838

Nugroho, Trisapto Wahyudi Agung. "Analisa Kebutuhan Pembimbing Kemasyarakatan Balai Pemasyarakatan (Bapas) Bandung", Jurnal Ilmiah Kebijakan $\begin{array}{lllll}\text { Hukum, } & \text { Vol. } & 13 & \text { No.1 } & \text { (2019): }\end{array}$ http://dx.doi.org/10.30641/kebijakan.2019.V13.69-84

Rukmi, Shinta, "Prospek Pidana Kerja Sosial di Indonesia", Jurnal Wacana Hukum, Vol. VII No. 1 (2008): 75-89, http://dx.doi.org/10.33061/1.jwh.2008.7.1.403

S, Tunggal \& Nathalina Naibaho, "Penjatuhan Kebiri Kimia bagi Pelaku Kejahatan Seksual Terhadap Anak dalam Perspektif Falsafah Pemidanaan", Jurnal Hukum $\mathcal{E}$ $\begin{array}{llllll}\text { Pembangunan, } & \text { Vol. } & 50 & \text { No. } & 2 & \text { (2020): }\end{array}$ http://dx.doi.org/10.21143/jhp.vol50.no2.2594

Slat, Teafani Kaunang, "Sanksi Pidana Kerja Sosial Terhadap Tindak Pidana Ringan Sebagai Upaya Pembaharuan Hukum Pidana Nasional", Jurnal Ilmiah Pendidikan Pancasila dan Kewarganegaraan, Vol. 4 No. 2 (2019): 352-360, http://dx.doi.org/10.17977/um019v4i2p352-360

Situmeang, Sahat Maruli Tua, Musa Darwin Pane \& Wahyudi, “Optimalisasi Peran Penegak Hukumdalam Menerapkan Pidana Kerja Sosial dan Ganti Rugi Guna Mewujudkan Tujuan Pemidanana yang Berkeadilan", Jurnal Ius Quia Iustum, Vol 27, Iss. 3 (2020): 501-525. https://doi.org/10.20885/iustum.vol27.iss3.art4

Sugiharto, Gatot, "Relevansi Kebijakan Penetapan Pidana Kerja Sosial dalam Sistem Pemidanaan di Indonesia", Jurnal Novelty, Vol. 7 No. 1 (2016): 83-96. http://dx.doi.org/10.26555/novelty.v7i3.a3936

Tirta, A. Leovaldi "Kekuatan Resolusi Majaleis Umum PBB (UNGA) daN Dewan Keamanan PBB (UNSC) sebagai Sumber Hukum Internasional", Jurnal Yustika, $\begin{array}{lllll}\text { Vol. } & 14 & \text { No. } & 1 & \text { 93-107, }\end{array}$ https://journal.ubaya.ac.id/index.php/yustika/article/view/1450

Wibawa, Iskandar, "Pidana Kerja Sosial Dan Restitusi Sebagai Alternatif Pidana Penjara dalam Pembaharuan Hukum Pidana Indonesia", Jurnal Media Hukum, Vol. 24, No. 2 (2017: 105-114), https://doi.org/10.18196/jmh.2017.0086.105-114

\section{Laporan}

Tim Penyusun Laporan Kinerja Instansi Pemerintah Ditjenpas 2020, Laporan Kinerja Direktorat Jenderal Pemasyarakatan Tahun 2020, (2021), Jakarta: Direktorat Jenderal Pemasyarakatan.

United Nations Asia and Far East Institute for the Prevention of Crime and the Treatment of Offenders (UNAFEI), Report of The Seminar: The 25th Anniversary Seminar of The United Nations Standard Minimum Rules for Non-Custodial Measures, (2015), Tokyo. 
Website

Direktorat Jenderal Pemasyarakatan Kementerian Hukum dan HAM Republik Indonesia, http://www.ditjenpas.go.id/atasi-overcrowded-ditjenpas-dukungrehabilitasi-pengguna-narkotika, Atasi Overcrowded, Ditjenpas Dukung Rehabilitasi Pengguna Narkotika, 2021.

asimilasi-di-rumah-bagi-narapidana-dan-anak-diperpanjang Penyebaran COVID-19, Asimilasi di Rumah bagi Narapidana dan Anak Diperpanjang, 2021. terintegrasi-pesantren-dan-panti-rehabilitasi-di-jawa-timur, Ditjenpas Akan Bangun Lapas Terintegrasi Pesantren dan Panti Rehabilitasi di Jawa Timur, 2021.

Ombudsman Republik Indonesia, https://ombudsman.go.id/news/r/ombudsmantemukan-rupbasan-dan-bapas-bermasalah, Ombudsman Temukan Rupbasan dan Bapas Bermasalah, 2021. 